\title{
Hypoxemia-induced leptin secretion: a mechanism for the control of food intake in diseased fish
}

\author{
Lauren E MacDonald, Sarah L Alderman, Sarah Kramer, Patrick T K Woo and \\ Nicholas J Bernier
}

Department of Integrative Biology, University of Guelph, 50 Stone Road East, Guelph, Ontario, Canada N1G 2W1

Correspondence should be addressed to $\mathrm{N} J$ Bernier

Email

nbernier@uoguelph.ca

\begin{abstract}
Leptin is a potent anorexigen, but little is known about the physiological conditions under which this cytokine regulates food intake in fish. In this study, we characterized the relationships between food intake, $\mathrm{O}_{2}$-carrying capacity, liver leptin-A1 (lep-a1) gene expression, and plasma leptin-A1 in rainbow trout infected with a pathogenic hemoflagellate, Cryptobia salmositica. As lep gene expression is hypoxia-sensitive and Cryptobia-infected fish are anemic, we hypothesized that Cryptobia-induced anorexia is mediated by leptin. A 14-week time course experiment revealed that Cryptobia-infected fish experience a transient $75 \%$ reduction in food intake, a sharp initial drop in hematocrit and hemoglobin levels followed by a partial recovery, a transient 17-fold increase in lep-a1 gene expression, and a sustained increase in plasma leptin-A1 levels. In the hypothalamus, peak anorexia was associated with decreases in mRNA levels of neuropeptide $Y$ (npy) and cocaineand amphetamine-regulated transcript (cart), and increases in agouti-related protein (agrp) and pro-opiomelanocortin A2 (pomc). In contrast, in non-infected fish pair-fed to infected animals, lep-a1 gene expression and plasma levels did not differ from those of non-infected satiated fish. Pair-fed fish were also characterized by increases in hypothalamic npy and agrp, no changes in pomc-a2, and a reduction in cart mRNA expression. Finally, peak infection was characterized by a significant positive correlation between $\mathrm{O}_{2}$-carrying capacity and food intake. These findings show that hypoxemia, and not feed restriction, stimulates leptin-A1 secretion in Cryptobia-infected rainbow trout and suggest that leptin contributes to anorexia by inhibiting hypothalamic npy and stimulating pomc-a2.
\end{abstract}
Key Words
- leptin
- appetite
- anemia
- fish disease
- parasites

Journal of Endocrinology (2014) 221, 441-455

\section{Introduction}

Leptin is recognized as playing an important role in the homeostatic control of feeding and energy expenditure in vertebrates (Ahima \& Flier 2000). In mammals, leptin is primarily produced by adipocytes and its circulating levels increase with overfeeding and decrease with fasting (Ahima et al. 1996, Walder et al. 1997). While leptin is a potent anorexigenic signal and stimulator of energy use, it does not suppress feeding and weight gain in obese individuals because of mechanisms that promote leptin resistance and energy conservation (Myers et al. 2008). Instead, the primary role of leptin in mammals is to communicate a state of energy deficiency to the brain, i.e. low leptin levels induce overfeeding and suppress energy expenditure (Flier 1998, Ahima 2008). In contrast, very

Published by Bioscientifica Ltd. 
little is known about the physiological roles of leptin in other vertebrate taxa. Although the tertiary structure of leptin is highly conserved, the low degree of primary sequence conservation among orthologs has delayed the characterization of leptin in non-mammalian vertebrates (Huising et al. 2006a). The recent cloning of fish leptins (see Londraville et al. (2014) for review), the recognition that several fish species express multiple leptin orthologs which may have led to the subfunctionalization of leptins in fish (Gorissen et al. 2009, Kurokawa \& Murashita 2009, Angotzi et al. 2013), and the development of research tools for leptins in fish (e.g. Kling et al. (2009)) offer new opportunities to determine the functional roles of this important metabolic signal in aquatic poikilotherms.

To date, fish studies on the regulation of lep expression and on the role of leptin in feeding suggest some conserved actions between teleosts and mammals but also fundamental differences. For example, although the liver is a major site of lep expression in fish, much lower levels have been detected in visceral adipose tissue (Huising et al. 2006b, Murashita et al. 2008, Rønnestad et al. 2010, Kobayashi et al. 2011, Won et al. 2012). As observed in mammals and in the African clawed frog (Xenopus laevis; Crespi \& Denver 2006), it is generally recognized that leptin is anorexigenic in fish. Although heterologous leptins have no effect on feeding in some species (Baker et al. 2000, Silverstein \& Plisetskaya 2000), feeding is reduced by i.p. and i.c.v. injections of murine and human leptin in goldfish (Carassius auratus; Volkoff et al. 2003, De Pedro et al. 2006), by i.p. injections of human leptin in striped bass (Morone saxatilis; Won et al. 2012), and by i.c.v. injection of human leptin in rainbow trout (Oncorhynchus mykiss; Aguilar et al. 2010). The i.p. injection of recombinant native leptin also reduces food intake in rainbow trout and affects the expression of hypothalamic appetite-regulating genes (Murashita et al. 2008). In contrast, in fish, a clear relationship between energy balance and lep expression has yet to be established. While prolonged fasting has no effect on the expression of liver lep in some species (Huising et al. 2006b, Gorissen et al. 2009, Kobayashi et al. 2011), it decreases (Gorissen et al. 2009, Won et al. 2012) or increases (Kling et al. 2009, Rønnestad et al. 2010, Fuentes et al. 2012) hepatic lep mRNA levels or leptin plasma levels in others. Thus, while leptin has anorectic actions, the physiological conditions under which it plays a role in the regulation of food intake in fish are still poorly understood.

Anorexia is a characteristic response to a variety of different viral, bacterial, and parasitic infections (Laviano et al. 2008, Bernier 2010). Among the different parasites known to affect feeding in fish, the effects of the pathogenic hemoflagellate, Cryptobia salmositica (order Parabodonida, class Kinetoplastea), on food intake in rainbow trout have been well characterized (Woo 2003). While the onset of anorexia in Cryptobia-infected fish coincides with a significant rise in parasitemia and a decrease in hematocrit, the return of appetite is associated with the establishment of an immune response that significantly reduces both the parasitemia and anemia (Li \& Woo 1991, Thomas \& Woo 1992, Chin et al. 2004). During acute infection, Cryptobia-infected fish are also characterized by a reduced aerobic scope (Kumaraguru et al. 1995) and an increased susceptibility to hypoxia (Woo \& Wehnert 1986). As leptin is a hypoxia-sensitive gene in mammals (Ambrosini et al. 2002) and fish (Chu et al. 2010), and its expression is stimulated by hypoxiainducible factor 1 (HIF1) in response to a deficiency in $\mathrm{O}_{2}$, we hypothesized that leptin contributes to the regulation of food intake in Cryptobia-infected rainbow trout.

In this study, to identify potential mechanisms mediating Cryptobia-induced anorexia, we first characterized the relationships between food intake, hepatic lepa1 expression, plasma leptin-A1 and the expression of key appetite-regulating genes in the hypothalamus of rainbow trout infected with C. salmositica. To differentiate between the effects of fasting from those of hypoxemia on the regulation food intake, we compared the effects of Cryptobia infection with those of restricted feeding on leptin signaling and the hypothalamic expression of appetite-regulating genes. Finally, we also examined the effects of Cryptobia infection on the $\mathrm{O}_{2}$-carrying capacity of rainbow trout and the relationship between $\mathrm{O}_{2}$-carrying capacity and food intake.

\section{Materials and methods}

\section{Experimental animals}

Rainbow trout of either sex were obtained from Rainbow Springs Trout Farm (Thamesford, ON, Canada) and housed in the Hagen Aqualab, University of Guelph (Guelph, ON, Canada). Fish were maintained in 8001 cylindrical tanks before experimental use and kept on a 12-h light:12-h darkness photoperiod cycle. All tanks were supplied with aerated and u.v.-treated well water at $12{ }^{\circ} \mathrm{C}$. Fish were fed daily ad libitum with commercial trout feed (4 PT Regular; Martin Mills, Elmira, ON, Canada). All procedures were carried out in accordance with the Canadian Council for Animal Care guidelines

Published by Bioscientifica Ltd 
and approved by the University of Guelph's Animal Care Committee.

\section{Experimental design}

Experiment 1: effects of Cryptobia infection on food intake, hematocrit, hemoglobin, liver lep-a1 expression, plasma leptin-A1, and the hypothalamic expression of appetite-regulating genes A total of 216 fish (145.7 $\pm 1.3 \mathrm{~g}$ ) were anesthetized in a buffered $\left(\mathrm{NaHCO}_{3}, 0.2 \mathrm{~g} / \mathrm{l}\right)$ solution of tricaine methanesulfonate $(0.1 \mathrm{~g} / 1$; MS-222; Syndel, Vancouver, BC, Canada), weighed, randomly assigned to one of 241251 tanks ( $n=9$ per tank), and acclimated to these conditions for at least 4 weeks. During this time and over the course of the experiment, fish were hand fed at $0900 \mathrm{~h}$ daily to satiation, i.e. the fish were fed until they showed no movement toward the feed. Duplicate tanks of fish were randomly assigned one of two treatments: i) an i.p. injection of PBS (150 $\mu$; control treatment) or ii) an i.p. injection of the parasite C. salmositica (TP4) at a dose of 100000 parasites in $150 \mu$ l of PBS (parasite treatment). The animals received i.p. injections under MS-222 anesthesia as mentioned earlier. Fish were terminally sampled at 1, 2, 3, 4, 8, and 14 weeks post-injection (wpi). On the day of sampling, fish were fed to satiation with trout feed labeled with X-ray-dense markers. Ninety minutes after feeding, all fish in a tank were terminally anesthetized at once with an overdose of 2-phenoxyethanol (2 ml/l, Sigma-Aldrich) and blood was obtained via caudal puncture using a $\mathrm{K}_{2}$ EDTA (0.5 M, pH 8.0)-treated syringe. The blood samples were used immediately to determine parasitemia, hematocrit, and hemoglobin concentration ( $n=18$ per treatment). The remaining blood was centrifuged at $14000 \mathrm{~g}$ for $3 \mathrm{~min}$ and the separated plasma was flash frozen in liquid nitrogen before storage at $-80{ }^{\circ} \mathrm{C}$ for later analysis of plasma leptin-A1 ( $n=12$ per treatment, i.e. six per tank). The liver was sampled to quantify the mRNA levels of lep-a1. At 4 wpi (peak anorexia), the brain was regionally dissected to isolate the hypothalamus according to the method of Bernier et al. (2008) and quantify the gene expression of neuropeptide $\mathrm{Y}(n p y)$, agoutirelated protein (agrp), pro-opiomelanocortin A2 (pomc$a 2$ ), and cocaine- and amphetamine-regulated transcript (cart). All tissues were immediately frozen in liquid nitrogen and stored at $-80{ }^{\circ} \mathrm{C}$ for future analysis $(n=8$ per treatment, i.e. four per tank). Individual food intake was quantified from all fish using X-radiography (see 'Food intake quantification' section).
Experiment 2: effects of Cryptobia infection or restricted feeding on food intake, plasma leptin-A1, and on the expression of lep-a1, interleukin $1 \beta$, and hypothalamic appetite-regulating genes A total of 48 fish $(206.0 \pm$ $3.2 \mathrm{~g}$ ) were used in this experiment. All fish were anesthetized as mentioned earlier, weighed, randomly assigned to one of six 1251 tanks ( $n=8$ per tank), and acclimated to these conditions for at least 4 weeks. During this time, and over the course of the experiment, all fish were fed daily at $0900 \mathrm{~h}$. Duplicate tanks of fish were randomly assigned one of three treatments: i) an i.p. injection of PBS $(150 \mu \mathrm{l})$ and satiation feeding (control treatment), ii) an i.p. injection of the parasite C. salmositica (TP4; 100000 parasites in $150 \mu \mathrm{lPB}$ ) and satiation feeding (parasite treatment), or iii) an i.p. injection of PBS $(150 \mu \mathrm{l})$ and pair feeding to the mean food intake consumed by the pathogen (TP4)-injected fish the day before (pair-fed treatment). All fish were killed at the time of maximal anorexia. This was considered as the point at which mean food intake of the pathogen-injected fish had reached a minimum and stayed at this level over a 3-day period. On the day of sampling, fish were fed to satiation with labeled trout feed. Ninety minutes after feeding, all fish within a tank were terminally anesthetized as above and blood was obtained via caudal puncture. The blood samples were used immediately to determine parasitemia, hematocrit, and hemoglobin concentration ( $n=16$ per treatment). The remaining blood was centrifuged as above to recover plasma for the analysis of leptin-A1 levels $(n=16$ per treatment), and the liver was sampled to quantify lep-a1 mRNA levels ( $n=12$ per treatment, i.e. six per tank). Given the role of pro-inflammatory cytokines such as interleukin $1 \beta$ (IL1 $\beta$ ) in mediating anorexia-cachexia in mammals (Laviano et al. 2008), both the head kidney and spleen were recovered to measure ill $\beta$ gene expression $(n=12$ per treatment, i.e. six per tank). As in Experiment 1, the hypothalamus was isolated to assess the expression of key hypothalamic appetite-regulating genes $(n=8$ per treatment, i.e. four per tank), and to quantify the mRNA levels of $i l 1 \beta$. Individual food intake was quantified from all fish using X-radiography.

Experiment 3: effects of Cryptobia infection on $\mathrm{O}_{2}$ carrying capacity A total of 33 fish $(198.8 \pm 4.8 \mathrm{~g})$ were used in this experiment. Each fish was anesthetized as above, weighed, and randomly assigned to one of three 1251 tanks ( $n=11$ per tank). Fish were acclimated and fed according to Experiment 1. At the onset of the study, each tank of fish was randomly assigned one of three treatments: i) an i.p. injection of PBS (150 $\mu \mathrm{l}$; control

Published by Bioscientifica Ltd 
treatment), ii) an i.p. injection of an attenuated form of C. salmositica (vaccine TV4; 100000 parasites in $150 \mu \mathrm{l}$ PBS; vaccine treatment), or iii) an i.p. injection of the parasite C. salmositica (TP4; 100000 parasites in $150 \mu \mathrm{l}$ PBS; parasite treatment). The attenuated vaccine strain of C. salmositica which does not cause disease (e.g. Woo \& Li (1990) and Beamish et al. (1996)) was used in Experiment 3. It was serially cultured in Minimum Essential Medium at $10^{\circ} \mathrm{C}$ over a 62 -week period before inoculation into the fish. All fish were terminally sampled at 3 wpi. On the day of sampling, fish were fed to satiation with labeled trout feed. Ninety minutes after feeding, all fish within a tank were rapidly and terminally anesthetized as above and blood samples were obtained via caudal puncture. The blood samples were used immediately to determine parasitemia, hematocrit, hemoglobin concentration ( $n=11$ per treatment), and $\mathrm{O}_{2}$-carrying capacity ( $n=8$ per treatment). Individual food intake was quantified from all fish using X-radiography.

Experiment 4: validation of Cryptobia vaccine In order to confirm that the attenuated vaccine strain of C. salmositica was generating protective immunity, 24 fish $(141.5 \pm 8.5 \mathrm{~g})$ were anesthetized as mentioned above, weighed, and randomly assigned to one of three 1251 tanks ( $n=8$ per tank). Fish were acclimated and fed according to Experiment 1. At the onset of the study, each tank of fish was randomly assigned one of three treatments: i) an i.p. injection of PBS (150 $\mu \mathrm{l}$; control treatment), ii) an i.p. injection of an attenuated form of C. salmositica (vaccine TV4; 100000 parasites in $150 \mu \mathrm{l}$ PBS; vaccine treatment), or iii) an i.p. injection of the parasite C. salmositica (TP4; 100000 parasites in $150 \mu \mathrm{l}$ PBS; parasite treatment). The attenuated vaccine strain of C. salmositica used in this experiment was the same as used above in Experiment 3. PBS-, vaccine-, and parasiteinjected fish were bled at 2 and 3 wpi to monitor parasitemia. At 5 wpi, both PBS- and vaccine-injected fish were challenged with an i.p. injection of the pathogenic strain (TP4; 100000 parasites in $150 \mu \mathrm{l} \mathrm{PBS}$ ). All pathogen-challenged fish were bled 2 and 4 weeks later to determine parasitemia.

\section{Parasitemia determination}

Whereas the absence of parasites in non-infected groups was confirmed using the wet mount technique (Woo 1979), parasitemia in the parasite-injected treatments was quantified using a Neubauer hemocytometer (Hausser Scientific, Horsham, PA, USA). Briefly, the collected blood was vortexed before and after dilution with PBS (21-fold dilution proved to be sufficient in all cases), dispensed to occupy each well of the hemocytometer, and the number of parasites counted.

\section{Assessment of hematological parameters and $\mathrm{O}_{2}$-carrying capacity}

Whole blood was collected in heparinized capillary tubes to determine hematocrit. The tubes were sealed, centrifuged at $13400 \boldsymbol{g}$ for $3 \mathrm{~min}$, and used to determine the ratio of erythrocytes in whole blood samples. Whole blood samples were also assayed immediately for hemoglobin concentration using a microplate assay. Briefly, a hemoglobin standard (15 g/dl; Pointe Scientific, Detroit, MI, USA) was sequentially diluted using Drabkin's solution (Sigma-Aldrich) to construct a standard curve. Blood samples were also diluted 1:250 using Drabkin's solution and allowed to incubate for $20 \mathrm{~min}$ at room temperature. The optical density of samples and standards were then read at $540 \mathrm{~nm}$ on a SpectraMAX 190 microplate reader using SOFTmax Software 4.6 (Molecular Devices, Menlo Park, CA, USA). Individual $\mathrm{O}_{2}$-carrying capacity was measured on whole blood using the modified method of Tucker (1967). The blood samples were allowed to equilibrate for $30 \mathrm{~min}$ in a tonometer supplied with $100 \%$ water-saturated air, kept at $32{ }^{\circ} \mathrm{C}$, and constantly agitated at 182 r.p.m. Following tonometry, $50 \mu \mathrm{l}$ blood samples were injected into a temperature-controlled $\left(32^{\circ} \mathrm{C}\right)$ tucker chamber, fitted with a Clark-type $\mathrm{O}_{2}$ electrode, and the change in $\mathrm{O}_{2}$ partial pressure was recorded using Labview Software (National Instruments, Austin, TX, USA).

\section{Food intake quantification}

On sampling days, fish were fed a labeled feed that could be detected using X-radiography. The regular diet (4 PT Regular, Martin Mills) was ground to a fine powder and re-pelleted with $450-\mu \mathrm{m}$ hardened cast carbon steel spheres (Draiswerke, Mahwah, NJ, USA) at a ratio of $5 \%$ by mass of dry powdered feed. Fish were X-rayed using an ACU-RAY HFJ portable X-ray unit (50 kV peak; $1.05 \mathrm{~mA} \cdot \mathrm{s}$ at $90 \mathrm{~cm}$; Sterne, Brampton, ON, Canada). Radiographs were developed, the individual spheres present in the gastrointestinal tract tallied and the amount of food consumed was determined using a calibration curve. Preliminary experiments showed that re-pelleting and diet labeling did not affect palatability.

Published by Bioscientifica Ltd. 


\section{Quantification of gene expression}

Total RNA was extracted using TRIzol Reagent (Life Technologies) and the concentrations quantified using u.v. spectrophotometery at $260 \mathrm{~nm}$ (Nanodrop 8000; Nanodrop Products, Wilmington, DE, USA). A random subset of samples from all treatment groups and sampling times were run on agarose gels to check for RNA integrity and genomic DNA contamination. One microgram of total RNA was treated with DNase I (DNase I amplification grade, Life Technologies) and reverse transcribed to cDNA using SuperScript II RNase $\mathrm{H}^{-}$reverse transcriptase (Life Technologies). Each cDNA sample was amplified using an ABI Prism 7000 sequence detection system (Applied Biosystems). Each reaction contained $10 \mu$ SYBR Green PCR Master Mix (Applied Biosystems), $5 \mu \mathrm{l}$ cDNA template diluted in 1:5 and $2.5 \mu \mathrm{l}$ each of forward and reverse primers $(0.4 \mu \mathrm{M})$ respectively. Default cycling conditions were used: $10 \mathrm{~min}$ at $95^{\circ} \mathrm{C}$ followed by 40 cycles of $15 \mathrm{~s}$ at $95^{\circ} \mathrm{C}$ and $1 \mathrm{~min}$ at $60^{\circ} \mathrm{C}$. This protocol was followed by a melting curve analysis to verify the specificity of the PCR products. To account for differences in amplification efficiency, standard curves were constructed for each target using serial dilutions of cDNA samples. Using the threshold cycle of each unknown, the relative dilution of a given sample was extrapolated using the linear regression of the target-specific standard curve. To correct for differences in template input and reverse transcriptase efficiencies, each sample was normalized to the expression level of the housekeeping gene, elongation factor $1 \alpha$ $(e f 1 \alpha)$. Note that the expression of ef $1 \alpha$ did not differ between any of the treatments $(P>0.05)$. All samples were assayed in triplicate and only one target was assayed per well. Finally, non-reverse transcribed RNA and water controls were run to ensure that no genomic DNA was being amplified and the reagents were not contaminated. Primer pairs for qRT-PCR were designed using Primer Express 3.0 (Applied Biosystems) based on rainbow trout sequences for each target gene (Table 1). Gene expression data is reported as fold change relative to the control treatment.

\section{Quantification of plasma leptin-A1 levels}

Plasma leptin-A1 concentrations were determined using RIA according to the methods of Kling et al. (2009). Briefly, a high antigenicity 14 amino-acid peptide ( $\operatorname{tLep}_{(110-123)}$ ) corresponding to the residues $110-123$ of rainbow trout leptin-A1 (accession no. AB354909) was synthesized (GenScript, Piscataway, NJ, USA). This peptide shares 71 and $21 \%$ sequence identity of rainbow trout leptin-A2 (accession no. JX123129) and leptin-B1 (accession no. JX131306) respectively (Angotzi et al. 2013). tLep $_{(110-123)}$ was subsequently used to immunize rabbits and produce affinity purified polyclonal antibodies (GenScript) and iodinated by the chloramine-T method to produce tracer. The incubation mixture for the standard curve consisted of $0.2 \mathrm{ml}$ standard (tLep $\left.{ }_{(110-123)}\right)$ and $0.05 \mathrm{ml}$ anti-tLep ${ }_{(110-123)}$ polyclonal antibody (1:1000 dilution). After $24 \mathrm{~h}$ at $4{ }^{\circ} \mathrm{C}$, $0.05 \mathrm{ml}{ }^{125}$ I-labeled $\operatorname{tLep}_{(110-123)}$ ( 10000 c.p.m.) was added to the mixture and incubated for another $24 \mathrm{~h}$ at $4{ }^{\circ} \mathrm{C}$. Bound antigen was precipitated with $0.1 \mathrm{ml}$ pansorbin cells (0.25\%; EMD Millipore, Billerica, MA, USA) for $5 \mathrm{~h}$ at $4{ }^{\circ} \mathrm{C}$ and thereafter centrifuged at $2000 \mathrm{~g}$ for $1 \mathrm{~h}$ at

Table 1 Nucleotide sequences of rainbow trout primers used for qRT-PCR

\begin{tabular}{|c|c|c|c|}
\hline Gene & Accession no. & Efficiency (\%) & Sequence $\left(5^{\prime} \rightarrow 3^{\prime}\right)$ \\
\hline agrp & CR376289 & 90.8 & $\begin{array}{l}\text { F: ACCAGCAGTCCTGTCTGGGTAA } \\
\text { R: AGTAGCAGATGGAGCCGAACA }\end{array}$ \\
\hline cart & CA380644 & 91.7 & $\begin{array}{l}\text { F: CCTCGACACAAGAAGTGTGAGAGA } \\
\text { R: TGTAGTGCTCCAAGCAGTTGCT }\end{array}$ \\
\hline ef $1 \alpha$ & AF498320 & 95.5 & $\begin{array}{l}\text { F: GGGCAAGGGCTCTTTCAAGT } \\
\text { R: CGCAATCAGCCTGAGAGGT }\end{array}$ \\
\hline$i l 1 \beta$ & AJ278242 & 85.7 & $\begin{array}{l}\text { F: ATGGGAACCGAGTTCAAGGA } \\
\text { R: AACACTATATGTTCTTCCACAGCACTCT }\end{array}$ \\
\hline lep-a1 & AB354909 & 95.1 & $\begin{array}{l}\text { F: GAGGGCATGGACCCATTTC } \\
\text { R: GGCAGGCTTTCTATATGCTGATC }\end{array}$ \\
\hline npy & AF203902 & 99.8 & $\begin{array}{l}\text { F: CGGTCAAACCCGAAAATCC } \\
\text { R: TCTTCCCATACCTCTGCCTTGT }\end{array}$ \\
\hline pomc-a2 & TC89514 & 87.4 & $\begin{array}{l}\text { F: CTGAAAACAACCTCCTGGAGTGT } \\
\text { R: GAGAGGAGGGACAGAGGTAAGTAGAG }\end{array}$ \\
\hline
\end{tabular}

agrp, agouti-related protein; cart, cocaine- and amphetamine-regulated transcript; ef1 $\alpha$, elongation factor $1 \alpha ; \mathrm{F}$, forward; il1 $\beta$, interleukin $1 \beta$; lep-a 1 , leptin$A 1$; npy, neuropeptide $Y$; pomc-a2, pro-opiomelanocortin A2; R, reverse.

${ }^{a}$ Expressed sequence tag (EST) contiguous from the rainbow trout gene index (www.tigr.org).

http://joe.endocrinology-journals.org DOI: 10.1530/JOE-13-0615 (c) 2014 Society for Endocrinology Printed in Great Britain
Published by Bioscientifica Ltd. 
$5{ }^{\circ} \mathrm{C}$. The supernatants were removed and precipitates counted on a WIZARD2 gamma counter (Perkin Elmer, Waltham, MA, USA). In the incubation mixture of unknown samples, the $0.2 \mathrm{ml}$ of standard ligand was replaced with rainbow trout plasma. All measurements were made in duplicate. The lowest detectable level of the leptin-A1 RIA was $250 \mathrm{pM}$. The dilution curve of immunoreactive leptin in rainbow trout plasma was parallel to the standard curve of tLep ${ }_{(110-123)}$ (Supplementary Fig. 1A, see section on supplementary data given at the end of this article). No cross-reactivity was detected between anti-tLep ${ }_{(110-123)}$ polyclonal antibody and recombinant rainbow trout growth hormone or insulin-like growth factor 1 (0.3-100 ng/ml; GroPep Bioreagents, Adelaide, SA, Australia). However, given the $71 \%$ sequence identity between residues the 110-123 of rainbow trout leptin-A1 and leptin-A2, we cannot exclude the possibility that our assay is also measuring leptin-A2. All samples were measured in a single assay and the intra-assay coefficient of variation was $5.9 \%(n=8)$.

Western blot analysis of full-length recombinant leptin-A in Arctic charr (Salvelinus alpinus; generously provided by Dr M M Vijayan (University of Calgary, Calgary, AB, Canada)) using the anti-tLep ${ }_{(110-123)}$ polyclonal antibody revealed specific binding at the expected molecular mass of $16 \mathrm{kDa}$ (Supplementary Fig. 1B). Leptin-A in Arctic charr (accession no. BAH83535) shares 71\% sequence identity with $\operatorname{tLep}_{(110-123)}$.

\section{Statistical analysis}

All data are presented as mean \pm s.E.M. For a given parameter in Experiments 1 and 2, differences between duplicate tanks were assessed by Student's $t$-test. Since no significant difference was observed between duplicate tanks, further statistical analysis was performed on combined data. In Experiment 1, differences in parasitemia between sampling times were assessed by a one-way ANOVA and by pairwise Tukey's post hoc test. A two-way ANOVA followed by a Holm-Sidak test for multiple comparisons was used to determine the effects of treatment and time on food intake, hematocrit, hemoglobin concentration, liver leptin gene expression, and plasma leptin-A1 levels. Differences between treatments in hypothalamic gene expression data were determined by Student's $t$-test. In Experiments 2 and 3, differences between treatments were assessed by a one-way ANOVA followed by a Tukey's post hoc test for all pairwise comparisons. In Experiment 4, a two-way ANOVA followed by a Holm-Sidak test for multiple comparisons was used to determine the effects of treatment and time on parasitemia. Data that did not meet the assumption of normality were log-transformed before analysis. The correlation between $\mathrm{O}_{2}$-carrying capacity and food intake in Experiment 3 was analyzed using Pearson's Product Moment Correlation. All analyses were performed using SigmaStat 3.0 (SPSS). The significance level for all statistical tests was $P<0.05$.

\section{Results}

Experiment 1: effects of Cryptobia infection on food intake, hematocrit, hemoglobin, liver lep-a1 expression, plasma leptin-A1, and the hypothalamic expression of appetite-regulating genes

C. salmositica infection caused severe disease in the pathogen-injected fish. Although C. salmositica infection was undetectable in the control fish, the number of blood parasites increased exponentially post-injection and peaked at $\sim 11 \times 10^{6}$ parasites $/ \mathrm{ml}$ at $3 \mathrm{wpi}$ in Cryptobiainfected fish. Parasitemia declined rapidly thereafter and remained at $\sim 0.5 \times 10^{6}$ parasites $/ \mathrm{ml}$ between 8 and 14 wpi (Fig. 1A). Hematocrit values in the parasite-injected fish fell to $50 \%$ when compared with those in the control fish at 3 and 4 wpi (Fig. 1B). With the decline in parasitemia, hematocrit values partially recovered in the pathogeninfected fish, but were still 29\% lower than that in controls by the end of the experiment. Similarly, peak infection with C. salmositica was associated with a $50 \%$ drop in hemoglobin concentrations and a partial recovery by 14 wpi that paralleled the changes in hematocrit (Fig. 1C). Relative to the control fish, food intake in the parasite treatment remained relatively unchanged during the first 2 wpi, quickly dropped by $75 \%$ at 3 wpi, and then gradually recovered back to control levels over the following 11 weeks (Fig. 1D). In general, fish infected with C. salmositica were characterized by an inverse relationship between food intake and liver lep-a1 gene expression. Liver lep-a1 gene expression in the parasite treatment increased 6.5- and 16.7-fold over control levels at 3 and 4 wpi, respectively, decreasing thereafter but remaining four times higher than control levels at 14 wpi (Fig. 1E). Plasma leptin-A1 in the parasite treatment also increased 1.6- and 1.7-fold over control levels at 3 and 4 wpi, respectively, and remained elevated through 14 wpi (Fig. 1F).

At $4 \mathrm{wpi}$, relative to the control treatment, fish infected with $C$. salmositica were characterized by significant changes in the hypothalamic expression of several appetite-regulating genes (Fig. 2). Interestingly, while the

Published by Bioscientifica Ltd. 
A

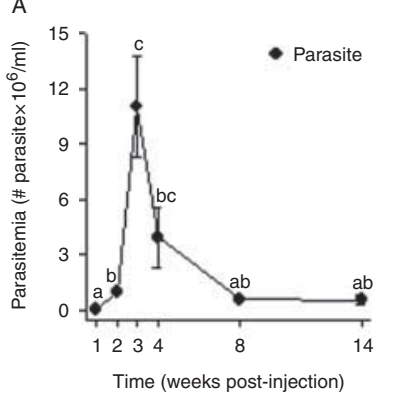

D

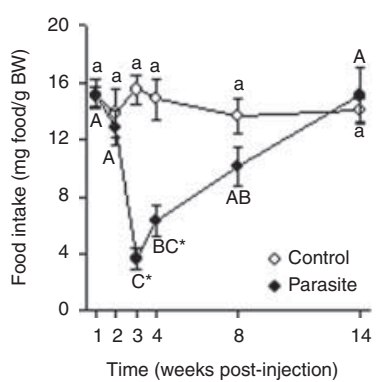

B

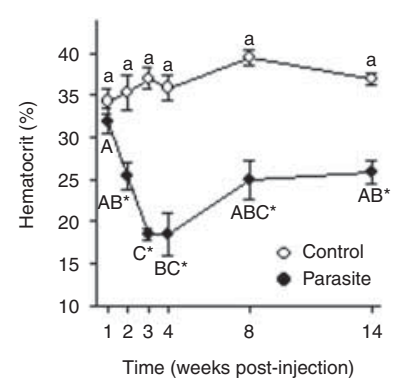

E

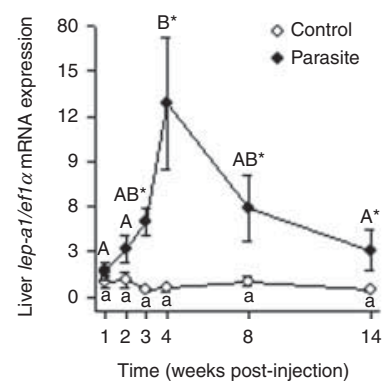

C

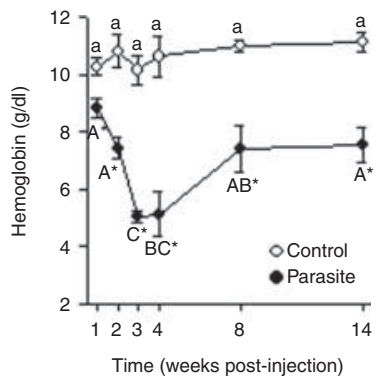

$\mathrm{F}$

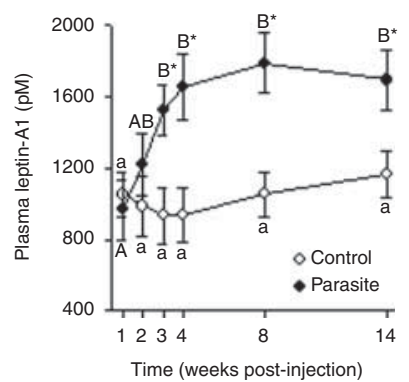

\section{Figure 1}

Effects of an i.p. injection of PBS (control treatment) or Cryptobia salmositica (100 000 parasites in PBS; parasite treatment) on (A) parasitemia $(n=18)$, (B) hematocrit $(n=18),(C)$ hemoglobin concentration $(n=18)$ (D) food intake $(n=18)$, (E) liver leptin-A1 (lep-a1) gene expression $(n=8)$, and (F) plasma leptin-A1 levels $(n=12)$. Parasites were not detected in the control treatment. The gene expression data are reported as the ratio of lep-a1:elongation factor $1 \alpha(e f 1 \alpha)$ mRNA levels and expressed relative to the value of the control treatment. Differences in parasitemia between sampling times were assessed by a one-way ANOVA and by pairwise Tukey's

reduction in food intake was associated with a decrease in $n p y$ mRNA levels, it was also characterized by an increase in the transcript levels of another orexigenic gene, agrp. Similarly, although $C$. salmositica infection resulted in a greater than twofold increase in pomc-a2 expression, it was also associated with a reduction in the mRNA levels of the anorexigenic gene, cart.

\section{Experiment 2: effects of Cryptobia infection or restricted feeding on food intake, plasma leptin-A1, and on the expression of lep-a1, il1 $\beta$, and hypothalamic appetite-regulating genes}

At the time of maximal anorexia, 25 days post-injection, numbers of blood parasite in the pathogen-injected fish were $4.53 \pm 1.14 \times 10^{6}$ parasites $/ \mathrm{ml}$. In contrast, parasites were not detected in either the control or pair-fed fish. The parasite-injected fish ate $77 \%$ less than the controls and the diet of the pair-fed fish was matched to that of the parasite treatment (Fig. 3A). In contrast, while the hematocrit and hemoglobin concentration of post hoc test. A two-way ANOVA followed by a Holm-Sidak test for multiple comparisons was used to determine the effects of treatment and time on food intake, hematocrit, hemoglobin concentration, liver lep-a1 gene expression, and plasma leptin-A1 levels. Sampling times within the control treatment that do not share a common lowercase letter, or within the parasite treatment that do not share an uppercase letter, are significantly different from each other. *Difference between treatments at a given time. The significance level for all statistical tests was $P<0.05$. Values are mean \pm S.E.M. BW, body weight.

the pathogen-injected fish were 62 and $75 \%$ lower than in the controls, respectively, there were no differences in either hematocrit or hemoglobin between the pair-fed and control fish (Supplementary Fig. 2A and B, see section on supplementary data given at the end of this article). Similarly, although the reduction in food intake in the parasite treatment was associated with an 8.7-fold increase in liver lep-a1 mRNA levels and a 1.8-fold increase in plasma leptin-A1, both lep-a1 gene expression and plasma levels did not differ between the pair-fed and control treatments (Fig. 3B and C). Finally, relative to the control and pair-fed fish, the $i l 1 \beta$ mRNA levels in the parasite treatment were markedly reduced in the head kidney and spleen (Fig. 3D and E) and unchanged in the hypothalamus (Fig. 3F).

Despite both having significantly reduced levels of food intake, the parasite and pair-fed fish were characterized by opposite changes in hypothalamic npy gene expression (Fig. 4). While parasite-induced appetite suppression was associated with lower npy mRNA levels, reduced feed availability in the pair-fed fish increased the

Published by Bioscientifica Ltd 


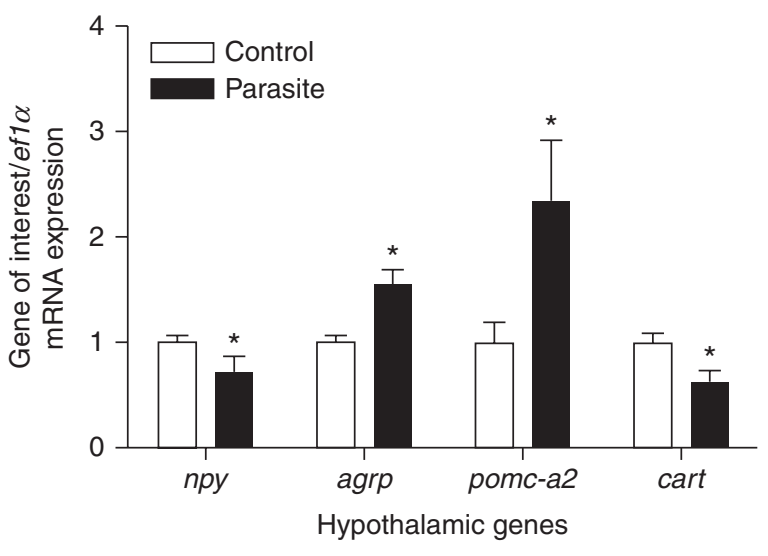

Figure 2

Effects of an i.p. injection of PBS (control treatment) or Cryptobia salmositica (100 000 parasites in PBS; parasite treatment) on the gene expression of hypothalamic neuropeptide $Y(n p y)$, agouti-related protein (agrp), pro-opiomelanocortin A2 (pomc-a2), and cocaine- and amphetamine-regulated transcript (cart). Fish were sampled at 4 weeks post-injection. The expression data are reported as the ratio of the gene of interest:elongation factor $1 \alpha$ (ef1 $\alpha$ ) mRNA levels and expressed relative to the value of the control treatment. *Difference between treatments for a given gene as determined by Student's $t$-test. The significance level for all statistical tests was $P<0.05(n=8)$. Values are mean + s. E.M.

expression of this transcript. In contrast, relative to satiated controls, both parasite-infected and pair-fed fish had increased agrp gene expression. As observed in Experiment 2, C. salmositica infection also resulted in a marked increase in pomc-a2 expression but pair feeding had no effect. Finally, the parasite and pair-fed treatments were both characterized with a decrease in hypothalamic cart gene expression, but the reduction only reached significance in the pair-fed fish.

\section{Experiment 3: effects of Cryptobia infection on $\mathrm{O}_{2}$-carrying capacity}

At the time of acute disease, i.e. at $3 \mathrm{wpi}$, the parasitemia of parasite-injected fish was 3.4 times higher than that in vaccine-injected fish (Fig. 5A). Relative to the PBSinjected control fish, both vaccine- and parasite-infected fish had reduced hematocrit (Fig. 5B) and hemoglobin concentration (Fig. 5C), but the effects were significantly more pronounced in the parasite treatment than in the vaccine treatment. Although food intake in the parasite-infected fish was reduced by $60 \%$, it was not significantly affected in the vaccinated fish (Fig. 5D). The $\mathrm{O}_{2}$-carrying capacity of the vaccine- and parasite-injected fish was respectively 34 and $61 \%$ lower than that in the controls (Fig. 5E). Overall, among the three treatments, there was a significant positive linear correlation
$\left(R^{2}=0.61, P<0.0001\right)$ between $\mathrm{O}_{2}$-carrying capacity and food intake (Fig. 5F).

\section{Experiment 4: validation of Cryptobia vaccine}

Parasites were detectable in the blood of both the vaccineand parasite-injected fish at 2 and 3 wpi, but the parasiteinjected fish had consistently higher parasite numbers (Supplementary Fig. 3A, see section on supplementary data given at the end of this article). Following challenge with the pathogenic $C$. salmositica at $5 \mathrm{wpi}$, previously vaccinated fish had similar parasite numbers to naïve fish at 2 weeks post-challenge and significantly lower parasitemia than naïve fish at 4 weeks post-challenge (Supplementary Fig. 3B).

\section{Discussion}

This study provides original evidence that the appetitesuppressing effects of $C$. salmositica infection in rainbow trout are associated with marked increases in hepatic lep-a1 mRNA expression and plasma leptin-A1 levels. During infection, maximum anorexia and lep-a1 mRNA expression correspond with the lowest hematocrit values, and at peak parasitemia there is a strong linear relationship between $\mathrm{O}_{2}$-carrying capacity and food intake. Using fish pair fed to the parasite treatment, we also demonstrate that the elevated plasma leptin-A1 levels of infected fish are not due to a reduction in food intake, and are specifically associated with a reduction in $n p y$ and an increase in pomc-a2 hypothalamic mRNA levels. Together, these results suggest that the expression of hepatic leptin in rainbow trout is stimulated by hypoxemic conditions and that the appetite-suppressing effects of $C$. salmositica infection are at least partly mediated by leptin.

The parasitemia and hematocrit changes observed in this study are consistent with the known progression of C. salmositica infection in salmonids (Woo \& Wehnert 1986, Beamish et al. 1996, Chin et al. 2004). The number of blood parasites peaked during acute infection at 3-4 wpi and subsequently declined in correspondence with a large increase in the production of Cryptobia-agglutinating antibodies (Sitja-Bobadilla \& Woo 1994, Chin et al. 2004). The anemic condition is caused by the direct lytic action of a Cryptobia-secreted metalloprotease along with complement-mediated destruction of antibody-coated erythrocytes and necrosis of hematopoietic tissues (Thomas \& Woo 1988, Zuo \& Woo 2000, Bahmanrokh \& Woo 2001). Herein, we show that the marked reduction in hemoglobin levels at peak parasitemia results in a

Published by Bioscientifica Ltd. 

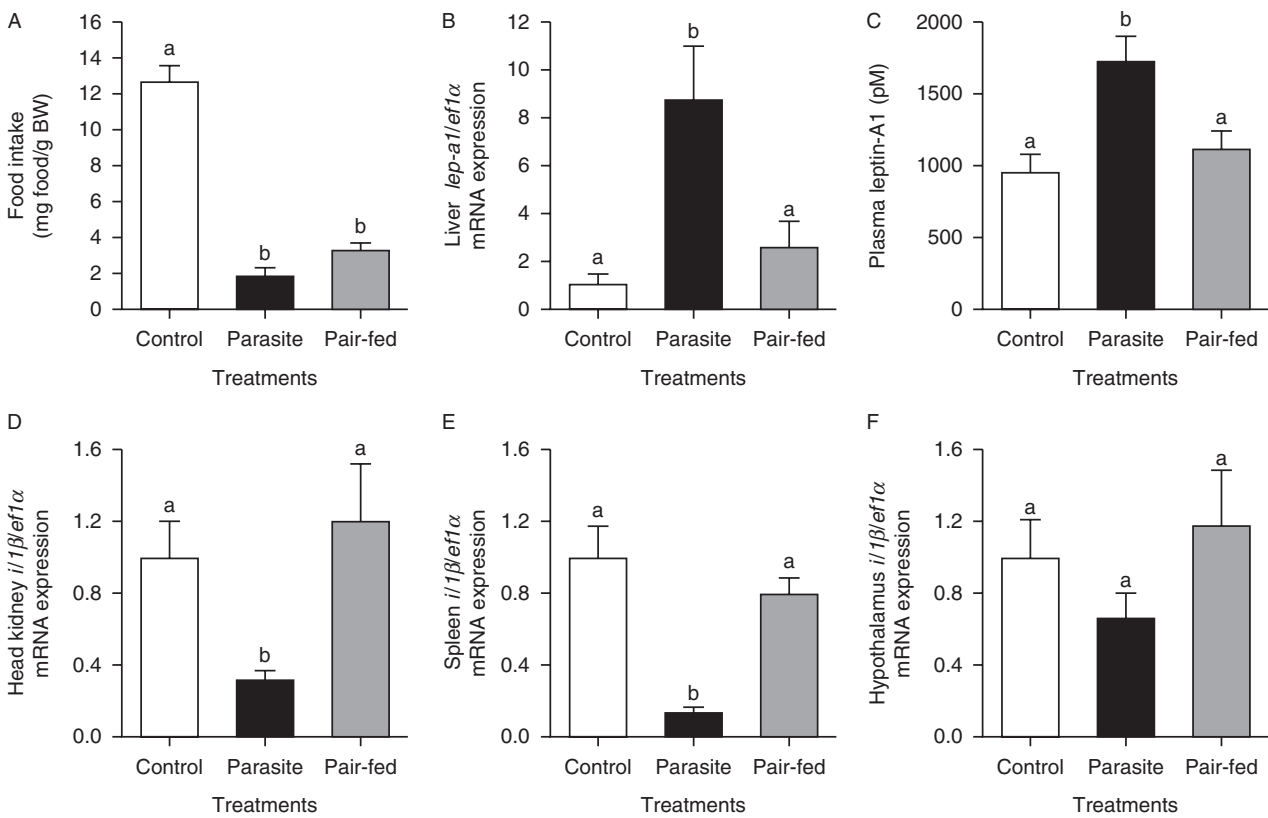

\section{Figure 3}

Effects of an i.p. injection of PBS (control treatment), Cryptobia salmositica (100 000 parasites in PBS; parasite treatment), or PBS and restricted feeding (pair-fed treatment) on (A) food intake $(n=16)$, (B) liver leptin-A1 (lep-a1) gene expression $(n=12)$, (C) plasma leptin-A1 levels $(n=16)$, (D) head kidney, (E) spleen, and (F) hypothalamus interleukin $1 \beta$ (il1 $\beta$ ) gene expression $(n=12)$. Whereas the control and parasite treatments were fed to satiation, the pair-fed treatment was fed the mean food intake consumed by the parasite treatment the day before. All fish were

significant decrease in $\mathrm{O}_{2}$-carrying capacity. Relative to parasite-injected fish, the smaller reduction in hemoglobin and $\mathrm{O}_{2}$-carrying capacity in the vaccinated fish concurs with the reduced ability of attenuated C. salmositica strains to produce the hemolytic metalloprotease (Zuo \& Woo 1997, Woo 2003). Overall, the hypoxemic state is consistent with the increased hypoxia susceptibility of Cryptobia-infected rainbow trout (Woo \& Wehnert 1986) and the reduced aerobic scope and swimming capacity associated with this disease (Kumaraguru et al. 1995).

Anorexia is also a distinctive clinical sign of C. salmositica infection (Thomas \& Woo 1992, Beamish et al. 1996, Chin et al. 2004). In this study, peak anorexia coincided with peak parasitemia as well as the lowest hematocrit and hemoglobin values. This relationship between anorexia, parasitemia and anemia has been previously reported in C. salmositica-infected fish (Woo 1979, Chin et al. 2004) and in mammals infected with the causative agent of sleeping sickness, Trypanosoma brucei (order Trypanosomatida, class Kinetoplastea) (Dumas \& Bisser 1999, Darsaud et al. 2003). While it is well terminally sampled at maximal anorexia, 25 days post-parasite injection. Parasites were not detected in the control and pair-fed treatments. The gene expression data is reported as the ratio of the gene of interest: elongation factor $1 \alpha$ (ef1 $\alpha$ ) mRNA levels and expressed relative to the value of the control treatment. Treatments that do not share a common letter are significantly different from each other as determined by a one-way ANOVA and pairwise Tukey's post hoc test. The significance level for all statistical tests was $P<0.05$. Values are mean + s.E.M.

established that chronic exposure to environmental hypoxia can reduce food intake in both hypoxia-sensitive and -tolerant fish species (e.g. Chabot \& Dutil (1999), Pichavant et al. (2001), Bernier \& Craig (2005) and Bernier et al. (2012)), previous studies have not directly examined the impact of hypoxemia on food intake. Herein, we show that acute infection with C. salmositica is characterized by a positive linear relationship between individual food intake and $\mathrm{O}_{2}$-carrying capacity.

The marked reduction in $\mathrm{O}_{2}$-carrying capacity during peak C. salmositica infection also corresponded with a sharp increase in hepatic lep-a1 mRNA expression and a significant increase in plasma leptin-A1 levels. These results are consistent with the observation that lep is a hypoxia-responsive gene and that its expression is stimulated by HIF1 in response to a reduction in $\mathrm{O}_{2}$ availability in both mammals (Ambrosini et al. 2002) and fish (Chu et al. 2010). While adipose tissue hypoxia (Hosogai et al. 2007, Wang et al. 2008) and exposure to hypobaric hypoxia (Chen et al. 2007, Simler et al. 2007) are associated with increases in lep mRNA expression and plasma leptin levels in mammals, chronic hypoxia also

Published by Bioscientifica Ltd 


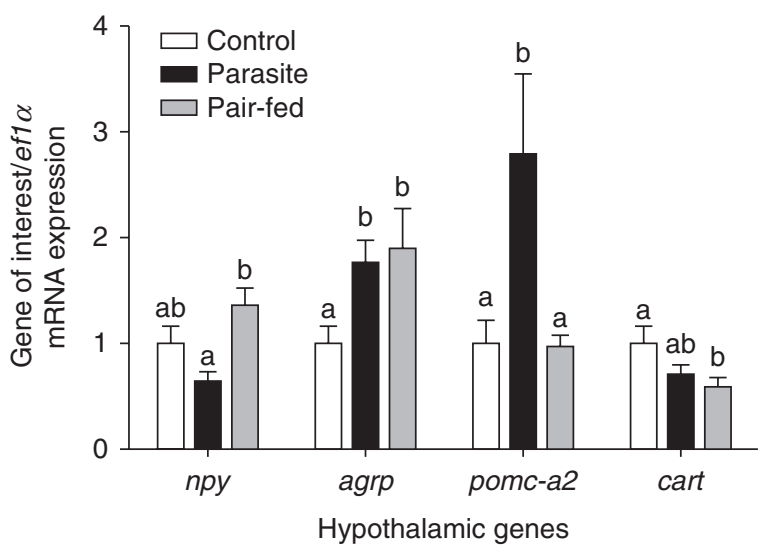

Figure 4

Effects of an i.p. injection of PBS (control treatment), Cryptobia salmositica (100 000 parasites in PBS; parasite treatment), or PBS and restricted feeding (pair-fed treatment) on the gene expression of hypothalamic neuropeptide $Y(n p y)$, agouti-related protein (agrp), pro-opiomelanocortin A2 (pomca2), and cocaine- and amphetamine-regulated transcript (cart). Whereas the control and parasite treatments were fed to satiation, the pair-fed treatment was fed the mean food intake consumed by the parasite treatment the day before. All fish were terminally sampled at maximal anorexia, 25 days post-parasite injection. The expression data are reported as the ratio of the gene of interest:elongation factor $1 \alpha$ (ef1 $\alpha)$ mRNA levels and expressed relative to the value of the control treatment. For a given gene, treatments that do not share a common letter are significantly different from each other as determined by a one-way ANOVA and pairwise Tukey's post hoc test. The significance level for all statistical tests was $P<0.05(n=8)$. Values are mean + S.E.M.

increases hepatic lep mRNA expression in fish (Chu et al. 2010, Bernier et al. 2012, Yu et al. 2012). Given the anorexigenic effects of leptin in rainbow trout (Murashita et al. 2008, Aguilar et al. 2010), the inverse relationship between hepatic lep-a1 mRNA expression and food intake in $C$. salmositica-infected fish and the increase in plasma leptin-A1 levels during acute infection suggest that leptin contributes to the regulation of food intake at peak parasitemia.

In contrast, the return to control food intake despite elevated plasma leptin-A1 levels during the chronic stage of $C$. salmositica infection, suggest a gradual desensitization to the anorectic actions of leptin. While a state of leptin resistance has not been previously described in fish, several mechanisms are known to reduce leptin signaling and promote leptin tolerance in obese individuals with chronically elevated plasma leptin levels (Myers et al. 2008, Schneeberger et al. 2013). In common carp, chronic hypoxia leads to a gradual reduction in hypothalamic leptin receptor (lepr) mRNA expression (Bernier et al. 2012). Similarly, changes in lepr expression or signaling within the hypothalamic feeding circuits of C. salmositica infected rainbow trout may be important for understanding the discrepancy between circulating leptin levels and appetite regulation. Interestingly, the high plasma leptin-A1 levels of the C. salmositica-infected fish between 4 and 14 wpi were sustained despite a significant decrease in hepatic lep-a1 mRNA expression. In chronically fasted rainbow trout, elevated plasma leptin levels are associated with reduced leptin-binding protein levels (Gong et al. 2013). Similarly, a reduction in plasma leptin-binding protein levels during the chronic stage of C. salmositica infection may serve to maintain high plasma leptin levels and explain the discrepancy between hepatic lep-a1 mRNA and plasma leptin levels. Alternatively, the clearance of leptin from the blood may slow down during chronic $C$. salmositica infection thereby increasing the half-life of plasma leptin.

Using fish pair fed to the parasite treatment, our results demonstrate that the marked increases in hepatic lep-a1 mRNA expression and plasma leptin-A1 levels of C. salmositica-infected rainbow trout are not due to a reduction in nutrient availability. While these results are consistent with previous studies, which failed to observe an effect of fasting on lep gene expression in some fish species (Huising et al. 2006b, Gorissen et al. 2009, Kobayashi et al. 2011, Tinoco et al. 2012), they also contrast with others where a positive relationship between fasting and hepatic lep mRNA expression has been observed. In rainbow trout (Kling et al. 2009), Atlantic salmon (Rønnestad et al. 2010, Trombley et al. 2012) and fine flounder (Paralichthys adspersus; Fuentes et al. 2012), fasting and restricted feeding have been associated with elevated plasma leptin levels. However, in those fish species where feed restriction can cause an increase in plasma leptin levels, the response is only observed after a minimum of 1 week of complete fast or several months of rationed feeding. In contrast, the reduction in food intake in C. salmositica-infected rainbow trout is transient and at peak anorexia the parasite-infected fish still consumes $\sim 25 \%$ of the ration in the control treatment.

The overall changes in the expression pattern of the hypothalamic appetite-regulating genes within the parasite-infected and pair-fed fish at peak anorexia also support a role for leptin in the regulation of food intake during C. salmositica infection. Leptin inhibits food intake in mammals by inhibiting the hypothalamic expression of the orexigenic signals, npy and agrp, and by stimulating the expression of the anorexigenic signals $\alpha$-melanocytestimulating hormone ( $\alpha$-MSH; a product of pomc) and cart (Ahima \& Flier 2000). In fish, the appetite-suppressing effects of native leptins have been associated with reductions in npy (Murashita et al. 2008, Li et al. 2010),

Published by Bioscientifica Ltd. 

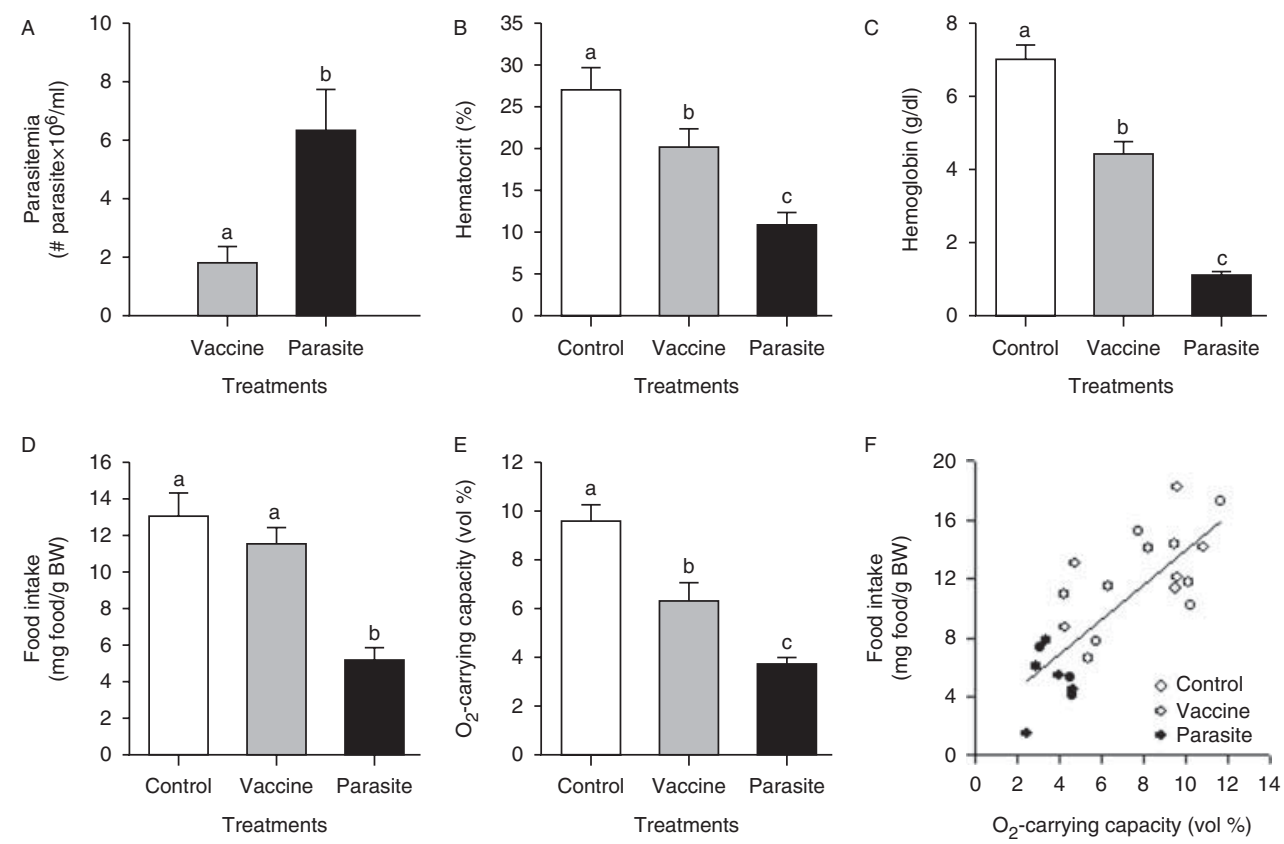

\section{Figure 5}

Effects of an i.p. injection of PBS (control treatment), an attenuated form of Cryptobia salmositica (100 000 parasites in PBS; vaccine treatment) or C. salmositica (100 000 parasites in PBS; parasite treatment) on (A) parasitemia ( $n=11)$, (B) hematocrit $(n=11)$, (C) hemoglobin concentration ( $n=11)$, (D) food intake ( $n=11)$, (E) blood $\mathrm{O}_{2}$-carrying capacity $(n=8)$, and $(F)$ the relationship between blood $\mathrm{O}_{2}$-carrying capacity, and individual food intake $(n=8)$. All fish were terminally sampled 3 weeks

increases in pomc (Murashita et al. 2008, 2011), and no change in agrp or cart (Murashita et al. 2011) hypothalamic mRNA expression. In vitro, human leptin also decreases hypothalamic $n p y$ mRNA levels, but does not have any direct effect on pomc or cart expression in rainbow trout (Aguilar et al. 2010). In contrast, feed deprivation in fish is generally associated with increases in the expression of $n p y$ and agrp, decreases in cart mRNA levels, and no change in pomc hypothalamic expression (Leder \& Silverstein 2006, Volkoff et al. 2009, Cerda-Reverter et al. 2011). Therefore, in this study, the reduction in $n p y$ and increase in pomc-a2 hypothalamic expression during peak anorexia in the parasite-infected fish are consistent with the known effects of recombinant native leptins in fish. Similarly, the parallel increases in agrp and decreases in cart mRNA levels during peak anorexia in the parasite and pair-fed treatments are consistent with the known effects of feed restriction on these transcripts and support the earlier observation that leptin may not affect the hypothalamic expression of these genes. Peak anorexia in C. salmositicainfected rainbow trout is also associated with a marked increase in the expression of brain preoptic area (POA) post-injection. Parasites were not detected in the control treatment. Treatments that do not share a common letter are significantly different from each other as determined by Student's $t$-test (parasitemia) or by a oneway ANOVA and pairwise Tukey's post hoc test. The relationship between $\mathrm{O}_{2}$-carrying capacity and food intake was analyzed using Pearson's product moment correlation test $\left(R^{2}=0.61, P<0.0001\right)$. The significance level for all statistical tests was $P<0.05(n=8-11)$. Values are mean + s.E.M.

corticotropin-releasing factor (crf; Madison et al. 2013), a potent anorexigenic signal in fish (Bernier 2006, Ortega et al. 2013). The fact that the anorexigenic action of $\alpha-\mathrm{MSH}$ is mediated by the CRF-signaling pathway in goldfish (Matsuda et al. 2008) and mice (Kawashima et al. 2008), suggest that POA CRF neurons may act as a downstream mediator of hypothalamic POMC neuron signaling and contribute to the regulation of food intake in Cryptobiainfected rainbow trout.

In addition to leptin, several other factors are known to contribute to anorexia (Carlton et al. 2012). Key among the signals that contribute to the regulation of food intake during infection are the pro-inflammatory cytokines IL1 $\beta$, IL6, and tumor necrosis factor alpha (TNF $\alpha$; Buchanan \& Johnson 2007). Produced both peripherally and centrally by cells of the innate immune system, these cytokines inhibit food intake in mammals through multiple pathways including the stimulation of leptin release (Sarraf et al. 1997). While the role of cytokines in the regulation of food intake in fish is largely unknown, peripheral injection of the pro-inflammatory cytokineinducing bacterial endotoxin, lipopolysaccharide, induces

Published by Bioscientifica Ltd. 
anorexia in goldfish (Volkoff \& Peter 2004). However, peak anorexia in Cryptobia-infected rainbow trout was associated with a marked reduction in il1 $\beta$ mRNA expression in the periphery and with no change in hypothalamic il1 $\beta$ mRNA levels. Also, while common carp (Cyprinus carpio) infected with a related hemoflagellate parasite, Trypanoplasma borreli (order Parabodonida, class Kinetoplastea), are characterized by an upregulation of $i l 1 \beta$ and $\operatorname{tnf} \alpha$ gene expression in the head kidney, liver, and spleen, the response generally peaks within 2 days of infection (Engelsma et al. 2003, Saeij et al. 2003). Although these preliminary results suggest that IL1 $\beta$ does not contribute to the regulation of food intake during peak C. salmositica infection in rainbow trout, an alternative explanation for the observed reduction in head kidney and spleen il1 $\beta$ gene expression is a redistribution and/or depletion of leukocyte populations from these hematopoietic tissues in response to infection. Moreover, multiple cytokines are known to have anorexigenic properties in mammals (Buchanan \& Johnson 2007). As such, we suggest that future studies are needed to directly assess the role of inflammatory cytokines in the regulation of food intake during infection in fish, as well as their potential contribution to the regulation of leptin secretion.

The role of leptin during C. salmositica infection in rainbow trout may not be limited to the regulation of food intake. For example, the inhibitory effects of leptin on pituitary adrenocorticotropin hormone secretion and interrenal cell cortisol production in fish (Gorissen et al. 2012), and its ability to suppress the expression of key adrenocortex steroidogenic enzymes in mammals (Kruse et al. 1998, Su et al. 2012) likely contribute to the blunted stress response and reduced cortisol synthesis capacity of C. salmositica-infected rainbow trout (Madison et al. 2013). Similarly, given the important roles of leptin in the regulation of hematopoiesis (Bennett et al. 1996), angiogenesis (Anagnostoulis et al. 2008), and the immune system (Carlton et al. 2012, Mariano et al. 2013), a promising avenue for future research in C. salmositicaand $T$. borreli-infected fish may be to explore the contribution of leptin to the regeneration of hematopoietic tissues during the chronic stage of infection and its effects on the innate and acquired immune responses that characterize these diseases (Woo \& Ardelli 2014). Recent studies in fish have shown that leptin can function as a hyperglycemic factor (Baltzegar et al. 2014) and stimulate metabolic rate (Dalman et al. 2013). Therefore, given the considerable bioenergetic cost of $C$. salmositica infection (Beamish et al. 1996, Woo 2003), leptin may also play an important role in regulating energy expenditure or promoting catabolic processes during the sustained phase of infection. Finally, a pleiotropic role for leptin during hypoxemic conditions in fish is suggested by the stimulatory effects of chronic hypoxia exposure on the expression of lepr in several peripheral tissues (Wong et al. 2007, Cao et al. 2011, Bernier et al. 2012).

Though a clinical sign of many diseases is a loss of appetite, very little is known about the specific mechanisms that mediate anorexia in diseased fish. In support of our hypothesis, our findings implicate leptin, in concert with other orexigenic (e.g. NPY) and anorexigenic (e.g. $\alpha$-MSH and CRF) neuropeptides, as a potential mediator of Cryptobia-induced anorexia. As previously observed in hypoxic common carp (Bernier et al. 2012), our results also suggest that hepatic lep gene expression in fish is more sensitive to deficits in $\mathrm{O}_{2}$ availability than in nutrient availability. Overall, as many fish pathogens bring about disease through the production of factors that are highly hemolytic or that agglutinate erythrocytes (Bernier 2010, Woo \& Bruno 2011), we suggest that leptin may mediate anorexia in a variety of fish diseases.

\section{Supplementary data}

This is linked to the online version of the paper at http://dx.doi.org/10.1530/ JOE-13-0615.

\section{Declaration of interest}

The authors declare that there is no conflict of interest that could be perceived as prejudicing the impartiality of the research reported.

\section{Funding}

This research was supported by grants to P T K W and N J B from Natural Sciences and Engineering Research Council of Canada (NSERC).

\section{Acknowledgements}

The authors thank Barry Madison, Erin Bristow, Sylvana Miller, and $\mathrm{Fu} \mathrm{Ci}$ Guo for their excellent technical assistance and Dr Dominique Bureau for his help in the development of the labeled feed used for food intake quantification. Dr M M Vijayan is gratefully acknowledged for providing us with recombinant Arctic charr leptin-A. The authors are also grateful to Drs James Ballantyne and Pat Wright for access to equipment and to Bob Frank and Matt Cornish for technical support in the Hagen Aqualab.

\section{References}

Aguilar AJ, Conde-Sieira M, Polakof S, Miguez JM \& Soengas JL 2010 Central leptin treatment modulates brain glucosensing function and peripheral energy metabolism of rainbow trout. Peptides 31 1044-1054. (doi:10.1016/j.peptides.2010.02.026) 
Ahima RS 2008 Revisiting leptin's role in obesity and weight loss. Journal of Clinical Investigation 18 2380-2383. (doi:10.1172/JCI36284)

Ahima RS \& Flier JS 2000 Leptin. Annual Review of Physiology 62 413-437. (doi:10.1146/annurev.physiol.62.1.413)

Ahima RS, Prabakaran D, Mantzoros C, Qu D, Lowell BB, Maratos-Flier E \& Flier JS 1996 Role of leptin in the neuroendocrine response to fasting. Nature 382 250-252. (doi:10.1038/382250a0)

Ambrosini G, Nath AK, Sierra-Honigmann MR \& Flores-Riveros J 2002 Transcriptional activation of the human leptin gene in response to hypoxia. Involvement of hypoxia-inducible factor 1 . Journal of Biological Chemistry 277 34601-34609. (doi:10.1074/jbc.M205172200)

Anagnostoulis S, Karayiannakis AJ, Lambropoulou M, Efthimiadou A, Polychronidis A \& Simopoulos C 2008 Human leptin induces angiogenesis in vivo. Cytokine 42 353-357. (doi:10.1016/j.cyto.2008. 03.009)

Angotzi AR, Stefansson SO, Nilsen TO, Rathore RM \& Rønnestad I 2013 Molecular cloning and genomic characterization of novel leptin-like genes in salmonids provide new insight into the evolution of the leptin gene family. General and Comparative Endocrinology 187 48-59. (doi:10.1016/j.ygcen.2013.03.022)

Bahmanrokh M \& Woo PTK 2001 Relations between histopathology and parasitaemias in Oncorhynchus mykiss infected with Cryptobia salmositica, a pathogenic haemoflagellate. Diseases of Aquatic Organisms 46 41-45. (doi:10.3354/dao046041)

Baker DM, Larsen DA, Swanson P \& Dickhoff WW 2000 Long-term peripheral treatment of immature coho salmon (Oncorhynchus kisutch) with human leptin has no clear physiologic effect. General and Comparative Endocrinology 118 134-138. (doi:10.1006/gcen.1999.7450)

Baltzegar DA, Reading BJ, Douros JD \& Borski RJ 2014 Role for leptin in promoting glucose mobilization during acute hyperosmotic stress in teleost fishes. Journal of Endocrinology 220 61-72. (doi:10.1530/JOE13-0292)

Beamish FWH, Sitja-Bobadilla A, Jebbink JA \& Woo PTK 1996 Bioenergetic cost of cryptobiosis in fish: rainbow trout Oncorhynchus mykiss infected with Cryptobia salmositica and with an attenuated live vaccine. Diseases of Aquatic Organisms 25 1-8. (doi:10.3354/dao025001)

Bennett BD, Solar GP, Yuan JQ, Mathias J, Thomas GR \& Matthews W 1996 A role for leptin and its cognate receptor in hematopoiesis. Current Biology 6 1170-1180. (doi:10.1016/S0960-9822(02)70684-2)

Bernier NJ 2006 The corticotropin-releasing factor system as a mediator of the appetite-suppressing effects of stress in fish. General and Comparative Endocrinology 146 45-55. (doi:10.1016/j.ygcen.2005.11.016)

Bernier NJ 2010 Food intake regulation and disorders. In Fish Diseases and Disorders, Volume 2: Non-Infectious Disorders, 2nd edn, pp 238-266. Eds J Leatherhead \& PTK Woo. Wallingford: CABI Publishing.

Bernier NJ \& Craig PM 2005 CRF-related peptides contribute to stress response and regulation of appetite in hypoxic rainbow trout. American Journal of Physiology. Regulatory, Integrative and Comparative Physiology 289 R982-R990. (doi:10.1152/ajpregu.00668.2004)

Bernier NJ, Alderman SL \& Bristow EN 2008 Heads or tails? Stressor-specific expression of corticotropin-releasing factor and urotensin I in the preoptic area and caudal neurosecretory system of rainbow trout Journal of Endocrinology 196 637-648. (doi:10.1677/JOE-07-0568)

Bernier NJ, Gorissen M \& Flik G 2012 Differential effects of chronic hypoxia and feed restriction on the expression of leptin and its receptor, food intake regulation and the endocrine stress response in common carp. Journal of Experimental Biology 215 2273-2282. (doi:10.1242/jeb. 066183)

Buchanan JB \& Johnson RW 2007 Regulation of food intake by inflammatory cytokines in the brain. Neuroendocrinology 86 183-190. (doi:10.1159/000108280)

Cao Y-B, Xue JL, Wu L-Y, Jiang W, Hu P-N \& Zhu J 2011 The detection of 3 leptin receptor isoforms in crucian carp gill and the influence of fasting and hypoxia in their expression. Domestic Animal Endocrinology $\mathbf{4 1}$ 74-80. (doi:10.1016/j.domaniend.2011.04.002)
Carlton ED, Demas GE \& French SS 2012 Leptin, a neuroendocrine mediator of immune responses, inflammation, and sickness behaviors. Hormones and Behavior 62 272-279. (doi:10.1016/j.yhbeh.2012.04.010)

Cerda-Reverter JM, Agulleiro MJ, R RG, Sanchez E, Ceinos R \& Rotllant J 2011 Fish melanocortin system. European Journal of Pharmacology 660 53-60. (doi:10.1016/j.ejphar.2010.10.108)

Chabot D \& Dutil JD 1999 Reduced growth of Atlantic cod in non-lethal hypoxic conditions. Journal of Fish Biology 55 472-491. (doi:10.1111/ j.1095-8649.1999.tb00693.x)

Chen XQ, Dong J, Niu CY, Fan JM \& Du JZ 2007 Effects of hypoxia on glucose, insulin, glucagon, and modulation by corticotropin-releasing factor receptor type 1 in the rat. Endocrinology 148 3271-3278. (doi:10.1210/en.2006-1224)

Chin A, Guo FC, Bernier NJ \& Woo PTK 2004 Effect of Cryptobia salmositicainduced anorexia on feeding behavior and immune response in juvenile rainbow trout Oncorhynchus mykiss. Diseases of Aquatic Organisms 58 17-26. (doi:10.3354/dao058017)

Chu DL, Li VW \& Yu RM 2010 Leptin: clue to poor appetite in oxygenstarved fish. Molecular and Cellular Endocrinology 319 143-146. (doi:10.1016/j.mce.2010.01.018)

Crespi EJ \& Denver RJ 2006 Leptin (ob gene) of the South African clawed frog Xenopus laevis. PNAS 103 10092-10097. (doi:10.1073/pnas. 0507519103)

Dalman MR, Liu Q, King MD, Bagatto B \& Londraville RL 2013 Leptin expression affects metabolic rate in zebrafish embryos (D. rerio). Frontiers in Physiology 4 160. (doi:10.3389/fphys.2013.00160)

Darsaud A, Bourdon L, Chevrier C, Keita M, Bouteille B, Queyroy A, Canini F, Cespuglio R, Dumas M \& Buguet A 2003 Clinical follow-up in the rat experimental model of African Trypanosomiasis. Experimental Biology and Medicine 228 1355-1362.

De Pedro N, Martinez-Alvarez R \& Delagado MJ 2006 Acute and chronic leptin reduces food intake and body weight in goldfish (Carassius auratus). Journal of Endocrinology 188 513-520. (doi:10.1677/joe. 1.06349)

Dumas M \& Bisser S 1999 Clinical aspects of human African Trypanosomiasis. In Progress in Human African Trypanosomiasis, Sleeping Sickness, pp 215-233. Eds M Dumas, B Bouteille \& A Buguet. Paris: Springer Verlag.

Engelsma MY, Stet RJM, Saeij JP \& Lidy Verburg-van Kemenade BM 2003 Differential expression and haplotypic variation of two interleukin-1 $\beta$ genes in the common carp (Cyprinus carpio L.). Cytokine 22 21-32. (doi:10.1016/S1043-4666(03)00102-9)

Flier JS 1998 What's in a name? In search of leptin's physiologic role Endocrinology 83 1407-1413.

Fuentes EN, Kling P, Einarsdottir IE, Alvarez M, Valdés JA, Molina A \& Björnsson BT 2012 Plasma leptin and growth hormone levels in the fine flounder (Paralichthys adspersus) increase gradually during fasting and decline rapidly after refeeding. General and Comparative Endocrinology 177 120-127. (doi:10.1016/j.ygcen.2012.02.019)

Gong N, Einarsdottir IE, Johansson M \& Björnsson BT 2013 Alternative splice variants of the rainbow trout leptin receptor encode multiple circulating leptin-binding proteins. Endocrinology 154 2331-2340. (doi:10.1210/en.2012-2082)

Gorissen M, Bernier NJ, Nabuurs SB, Flik G \& Huising MO 2009 Two divergent leptin paralogues in zebrafish (Danio rerio) that originate early in teleostean evolution. Journal of Endocrinology 201 329-339. (doi:10.1677/JOE-09-0034)

Gorissen M, Bernier NJ, Manuel R, de Gelder S, Metz JR, Huising MO \& Flik G 2012 Recombinant human leptin attenuates stress axis activity in common carp (Cyprinus carpio L.). General and Comparative Endocrinology 178 75-81. (doi:10.1016/j.ygcen.2012.04.004)

Hosogai N, Fukuhara A, Oshima K, Miyata Y, Tanaka S, Segawa K, Furukawa S, Tochino Y, Komuro R, Matsuda M et al. 2007 Adipose tissue hypoxia in obesity and its impact on adipocytokine dysregulation. Diabetes 56 901-911. (doi:10.2337/db06-0911) http://joe.endocrinology-journals.org DOI: 10.1530/JOE-13-0615
() 2014 Society for Endocrinology Printed in Great Britain 
Huising MO, Kruiswijk CP \& Flik G 2006a Phylogeny and evolution of class-I helical cytokines. Journal of Endocrinology 189 1-25. (doi:10.1677/joe.1.06591)

Huising MO, Geven EJ, Kruiswijk CP, Nabuurs SB, Stolte EH, Spanings FA, Verburg-van Kemenade BM \& Flik G $2006 b$ Increased leptin expression in common carp (Cyprinus carpio) after food intake but not after fasting or feeding to satiation. Endocrinology 147 5786-5797. (doi:10.1210/en. 2006-0824)

Kawashima S, Sakihara S, Kageyama K, Nigawara T \& Suda T 2008 Corticotropin-releasing factor (CRF) is involved in the acute anorexic effect of $\alpha$-melanocyte-stimulating hormone: a study using CRFdeficient mice. Peptides 292 2169-2174. (doi:10.1016/j.peptides. 2008.09.010)

Kling P, Ronnestad I, Stefansson SO, Murashita K, Kurokawa T \& Björnsson BT 2009 A homologous salmonid leptin radioimmunoassay indicates elevated plasma leptin levels during fasting of rainbow trout. General and Comparative Endocrinology 162 307-312. (doi:10.1016/ j.ygcen.2009.04.003)

Kobayashi Y, Quiniou S, Booth NJ \& Peterson BC 2011 Expression of leptin-like peptide (LLP) mRNA in channel catfish (Ictalurus punctatus) is induced by exposure to Edwardsiella ictaluri but is independent of energy status. General and Comparative Endocrinology 173 411-418. (doi:10.1016/j.ygcen.2011.06.011)

Kruse M, Bornstein SR, Uhlmann K, Paeth G \& Scherbaum WA 1998 Leptin down-regulates the steroid producing system in the adrenal. Endocrine Research 24 587-590. (doi:10.3109/07435809809032650)

Kumaraguru AK, Beamish FWH \& Woo PTK 1995 Impact of a pathogenic haemoflagellate, Cryptobia salmositica Katz, on the metabolism and swimming performance of rainbow trout, Oncorhynchus mykiss (Walbaum). Journal of Fish Diseases 18 297-305. (doi:10.1111/j.13652761.1995.tb00306.x)

Kurokawa T \& Murashita K 2009 Genomic characterization of multiple leptin genes and a leptin receptor gene in the Japanese medaka, Oryzias latipes. General and Comparative Endocrinology $161229-237$. (doi:10.1016/j.ygcen.2009.01.008)

Laviano A, Inui A, Marks DL, Meguid MM, Pichard C, Fanelli FR \& Seelaender M 2008 Neural control of the anorexia-cachexia syndrome. American Journal of Physiology. Endocrinology and Metabolism 295 E1000-E1008. (doi:10.1152/ajpendo.90252.2008)

Leder EH \& Silverstein JT 2006 The pro-opiomelanocortin genes in rainbow trout (Oncorhynchus mykiss): duplications, splice variants, and differential expression. Journal of Endocrinology 188 355-363. (doi:10.1677/joe.1.06283)

Li S \& Woo PTK 1991 Anorexia reduces the severity of cryptobiosis in Oncorhynchus mykiss. Journal of Parasitology 77 467-471. (doi:10.2307/ 3283137)

Li GG, Liang XF, Xie Q, Li G, Yu Y \& Lai K 2010 Gene structure, recombinant expression and functional characterization of grass carp leptin. General and Comparative Endocrinology 166 117-127. (doi:10.1016/j.ygcen.2009.10.009)

Londraville RL, Macotela Y, Duff RJ, Easterling MR, Liu Q \& Crespi EJ 2014 Comparative endocrinology of leptin: assessing function in a phylogenetic context. General and Comparative Endocrinology [in press]. (doi:10.1016/j.ygcen.2014.02.002)

Madison BN, Woo PTK \& Bernier NJ 2013 Duress without stress: Cryptobia infection results in HPI axis dysfunction in rainbow trout. Journal of Endocrinology 218 287-297. (doi:10.1530/JOE-13-0155)

Mariano G, Stilo R, Terrazzano G, Coccia E, Vito P, Varricchio E \& Paolucci M 2013 Effects of recombinant trout leptin in superoxide production and NF-кB/MAPK phosphorylation in blood leukocytes. Peptides 48 59-69. (doi:10.1016/j.peptides.2013.07.026)

Matsuda K, Kojima K, Shimakura S, Wada K, Maruyama K, Uchiyama M, Kikuyama S \& Shioda S 2008 Corticotropin-releasing hormone mediates $\alpha$-melanocyte-stimulating hormone-induced anorexigenic action in goldfish. Peptides 29 1930-1936. (doi:10.1016/j.peptides. 2008.06.028)
Murashita K, Uji S, Yamamoto T, Rønnestad I \& Kurokawa T 2008 Production of recombinant leptin and its effects on food intake in rainbow trout (Oncorhynchus mykiss). Comparative Biochemistry and Physiology 150B 377-384. (doi:10.1016/j.cbpb.2008.04.007)

Murashita K, Jordal AE, Nilsen TO, Stefansson SO, Kurokawa T, Bjornsson BT, Moen AG \& Rønnestad I 2011 Leptin reduces Atlantic salmon growth through the central pro-opiomelanocortin pathway. Comparative Biochemistry and Physiology 158A 79-86. (doi:10.1016) j.cbpa.2010.09.001)

Myers MG, Cowley MA \& Münzberg H 2008 Mechanisms of leptin action and leptin resistance. Annual Review of Physiology 70 537-556. (doi:10.1146/annurev.physiol.70.113006.100707)

Ortega VA, Lovejoy DA \& Bernier NJ 2013 Appetite-suppressing effects and interactions of centrally administered corticotropin-releasing factor, urotensin I and serotonin in rainbow trout (Oncorhynchus mykiss). Frontiers in Neuroscience 7 196. (doi:10.3389/fnins.2013.00196)

Pichavant K, Person-Le-Ruyet J, Le Bayon N, Severe A, Le Roux A \& Boeuf G 2001 Comparative effects of long-term hypoxia on growth, feeding and oxygen consumption in juvenile turbot and European sea bass. Journal of Fish Biology 59 875-883. (doi:10.1111/j.1095-8649.2001. tb00158.x)

Rønnestad I, Nilsen TO, Murashita K, Angotzi AR, Moen AG, Stefansson SO, Kling P, Björnsson BT \& Kurokawa T 2010 Leptin and leptin receptor genes in Atlantic salmon: cloning, phylogeny, tissue distribution and expression correlated to long-term feeding status. General and Comparative Endocrinology 168 55-70. (doi:10.1016/j.ygcen.2010.04.010)

Saeij JPJ, Vries BJD \& Wiegertjes GF 2003 The immune response of carp to Trypanoplasma borreli: kinetics of immune gene expression and polyclonal lymphocyte activation. Developmental and Comparative Immunology 27 859-874. (doi:10.1016/S0145-305X(03)00083-1)

Sarraf P, Frederich RC, Turner EM, Ma G, Jaskowiak NT, Rivet DJ III, Flier JS, Lowell BB, Fraker DL \& Alexander HR 1997 Multiple cytokines and acute inflammation raise mouse leptin levels: potential role in inflammatory anorexia. Journal of Experimental Medicine 185 171-175. (doi:10.1084/jem.185.1.171)

Schneeberger M, Dietrich MO, Sebastián D, Imbernón M, Castaño C, Garcia A, Esteban Y, Gonzalez-Franquesa A, Rodríguez IC, Bortolozzi A et al. 2013 Mitofusin 2 in POMC neurons connects ER stress with leptin resistance and energy imbalance. Cell 155 172-187. (doi:10.1016/j.cell. 2013.09.003)

Silverstein JT \& Plisetskaya EM 2000 The effects of NPY and insulin on food intake regulation in fish. American Zoologist 40 296-308. (doi:10.1668/ 0003-1569(2000)040[0296:TEONAI]2.0.CO;2)

Simler N, Malgoyre A, Koulmann N, Alonso A, Peinnequin A \& Bigard AX 2007 Hypoxic stimulus alters hypothalamic AMP-activated protein kinase phosphorylation concomitant to hypophagia. Journal of Applied Physiology 102 2135-2141. (doi:10.1152/japplphysiol.01150.2006)

Sitja-Bobadilla A \& Woo PTK 1994 An enzyme-linked immunosorbent assay (ELISA) for the detection of antibodies against the pathogenic haemoflagellate, Cryptobia salmositica (Katz), and protection against cryptobiosis in juvenile rainbow trout, Oncorhynchus mykiss (Walbaum), inoculated with a live vaccine. Journal of Fish Diseases $\mathbf{1 7}$ 399-408. (doi:10.1111/j.1365-2761.1994.tb00235.x)

Su Y, Carey LC, Rose JC \& Pulgar VM 2012 Leptin alters adrenal responsiveness by decreasing expression of ACTH-R, StAR, and P450c21 in hypoxemic fetal sheep. Reproductive Sciences 19 1075-1084. (doi:10.1177/1933719112442246)

Thomas PT \& Woo PTK 1988 Cryptobia salmositica: an in vitro and in vivo study on the mechanism of anaemia in infected rainbow trout, Salmo gairdneri Richardson. Journal of Fish Diseases 11 425-431. (doi:10.1111/ j.1365-2761.1988.tb00738.x)

Thomas PT \& Woo PTK 1992 Anorexia in rainbow trout, Oncorhynchus mykiss (Walbaum), infected with Cryptobia salmositica (Sarcomastigophora: Kinetoplastida): its onset and contribution to the immunodepression. Journal of Fish Diseases 15 443-447. (doi:10.1111/j.1365-2761. 1992.tb01245.x)

Published by Bioscientifica Lto. 
Tinoco AB, Nisembaum LG, Isorna E, Delgado MJ \& De Pedro N 2012 Leptins and leptin receptor expression in the goldfish (Carassius auratus). Regulation by food intake and fasting / overfeeding conditions. Peptides 34 329-335. (doi:10.1016/j.peptides.2012.02.001)

Trombley S, Maugars G, Kling P, Bjornsson BT \& Schmitz M 2012 Effects of long-term restricted feeding on plasma leptin, hepatic leptin expression and leptin receptor expression in juvenile Atlantic salmon (Salmo salar L.). General and Comparative Endocrinology 175 92-99. (doi:10.1016/ j.ygcen.2011.10.001)

Tucker VA 1967 Method for oxygen content and dissociation curves on microliter blood samples. Journal of Applied Physiology 23 410-414.

Volkoff H \& Peter RE 2004 Effects of lipopolysaccharide treatment on feeding of goldfish: role of appetite-regulating peptides. Brain Research 998 139-147. (doi:10.1016/j.brainres.2003.11.011)

Volkoff H, Eykelbosh AJ \& Peter RE 2003 Role of leptin in the control of feeding of golfish Carassius auratus: interactions with cholecystokinin, neuropeptide $\mathrm{Y}$ and orexin $\mathrm{A}$, and modulation by fasting. Brain Research 972 90-109. (doi:10.1016/S0006-8993(03)02507-1)

Volkoff H, Unniappan S \& Kelly SP 2009 The endocrine regulation of food intake. In Fish Neuroendocrinology, Fish Physiology, pp 421-465. Eds NJ Bernier, G Van Der Kraak, AP Farrell \& CJ Brauner. Burlington: Academic Press.

Walder K, Willet M, Zimmet P \& Collier GR 1997 Ob (obese) gene expression and leptin levels in Psammomys obesus. Biochimica et Biophysica Acta 1354 272-278. (doi:10.1016/S0167-4781(97)00083-3)

Wang B, Wood IS \& Trayhurn P 2008 Hypoxia induces leptin gene expression and secretion in human preadipocytes: differential effects of hypoxia on adipokine expression by preadipocytes. Journal of Endocrinology 198 127-134. (doi:10.1677/JOE-08-0156)

Won ET, Baltzegar DA, Picha ME \& Borski RJ 2012 Cloning and characterization of leptin in a perciform fish, the striped bass (Morone saxatilis): control of feeding and regulation by nutritional state. General and Comparative Endocrinology 178 98-107. (doi:10.1016/ j.ygcen.2012.04.019)
Wong MM, Yu RM, Ng PK, Law SH, Tsang AK \& Kong RY 2007 Characterization of a hypoxia-responsive leptin receptor (omLepR(L)) cDNA from the marine medaka (Oryzias melastigma). Marine Pollution Bulletin 54 797-803. (doi:10.1016/j.marpolbul.2007.01.025)

Woo PTK 1979 Trypanoplasma salmositica: experimental infections in rainbow trout, Salmo gairdneri. Experimental Parasitology 47 36-48. (doi:10.1016/0014-4894(79)90005-5)

Woo PTK 2003 Cryptobia (Trypanoplasma) salmositica and salmonid cryptobiosis. Journal of Fish Diseases 26 627-646. (doi:10.1046/j.13652761.2003.00500.x)

Woo PTK \& Ardelli BF 2014 Immunity against selected piscine flagellates. Developmental and Comparative Immunology 2 268-279. (doi:10.1016/ j.dci.2013.07.006)

Woo PTK \& Bruno DW 2011 In Fish Diseases and Disorders, Volume 3: Viral, Bacterial and Fungal Infections, 2nd edn, p 940. Wallingford, Oxfordshire, UK: CABI Publishing.

Woo PTK \& Li S 1990 In vitro attenuation of Cryptobia salmositica and its use as a live vaccine against cryptobiosis in Oncorhynchus mykiss. Journal of Parasitology 76 752-755. (doi:10.2307/3283000)

Woo PTK \& Wehnert SD 1986 Cryptobia salmositica: susceptibility of infected rainbow trout, Salmo gairderi, to environmental hypoxia. Journal of Parasitology 72 392-396. (doi:10.2307/3281678)

Yu RM, Chu DL, Tan TF, Li VW, Chan AK, Giesy JP, Cheng SH, Wu RS \& Kong RY 2012 Leptin-mediated modulation of steroidogenic gene expression in hypoxic zebrafish embryos: implications for the disruption of sex steroids. Environmental Science \& Technology $\mathbf{4 6}$ 9112-9119. (doi:10.1021/es301758c)

Zuo X \& Woo PTK 1997 Proteases in pathogenic and nonpathogenic haemoflagellates, Cryptobia spp. (Sarcomastigophora: Kinetoplastida), of fishes. Diseases of Aquatic Organisms 29 57-65. (doi:10.3354/ dao029057)

Zuo X \& Woo PTK 2000 In vitro haemolysis of piscine erythrocytes by purified metallo-protease from the pathogenic haemoflagellate, Cryptobia salmositica Katz. Journal of Fish Diseases 23 227-230. (doi:10.1046/j.1365-2761.2000.00221.x)

Received in final form 31 March 2014

Accepted 9 April 2014

Accepted Preprint published online 16 April 2014 http://joe.endocrinology-journals.org DOI: 10.1530/JOE-13-0615
() 2014 Society for Endocrinology Printed in Great Britain
Published by Bioscientifica Ltd. 